\title{
Identification of disease- and headache- specific mediators and pathways in migraine using blood transcriptomic and metabolomic analysis
}

Timea Aczél ${ }^{1 \dagger}$, Tamás Körtési²,3,4† ${ }^{2}$ József Kun ${ }^{1,5 \dagger}$, Péter Urbán ${ }^{5}$, Witold Bauer ${ }^{5}$, Róbert Herczeg ${ }^{5}$, Róbert Farkas ${ }^{6}$, Krisztián Kovács ${ }^{6}$, Barna Vásárhelyi ${ }^{6}$, Gellért B. Karvaly ${ }^{6}$, Attila Gyenesei ${ }^{5}$, Bernadett Tuka ${ }^{2,3}$, János Tajti ${ }^{2}$, László Vécsei ${ }^{2,3}$, Kata Bölcskei ${ }^{1 \dagger}$ (D) and Zsuzsanna Helyes ${ }^{1 *+}$

\begin{abstract}
Background: Recent data suggest that gene expression profiles of peripheral white blood cells can reflect changes in the brain. We aimed to analyze the transcriptome of peripheral blood mononuclear cells (PBMC) and changes of plasma metabolite levels of migraineurs in a self-controlled manner during and between attacks.

Methods: Twenty-four patients with migraine were recruited and blood samples were collected in a headache-free (interictal) period and during headache (ictal) to investigate disease- and headache-specific alterations. Control samples were collected from 13 age- and sex-matched healthy volunteers. RNA was isolated from PBMCs and single-end 75 bp RNA sequencing was performed using Illumina NextSeq 550 instrument followed by gene-level differential expression analysis. Functional analysis was carried out on information related to the role of genes, such as signaling pathways and biological processes. Plasma metabolomic measurement was performed with the Biocrates MxP Quant 500 Kit.

Results: We identified 144 differentially-expressed genes in PBMCs between headache and headache-free samples and 163 between symptom-free patients and controls. Network analysis revealed that enriched pathways included inflammation, cytokine activity and mitochondrial dysfunction in both headache and headache-free samples compared to controls. Plasma lactate, succinate and methionine sulfoxide levels were higher in migraineurs while spermine, spermidine and aconitate were decreased during attacks.
\end{abstract}

Conclusions: It is concluded that enhanced inflammatory and immune cell activity, and oxidative stress can play a role in migraine susceptibility and headache generation.

Keywords: Migraine, Transcriptomic analysis, Peripheral blood mononuclear cells, Cytokines, Mitochondrial dysfunction

\footnotetext{
*Correspondence: zsuzsanna.helyes@aok.pte.hu

${ }^{\dagger}$ Timea Aczél, Tamás Körtési, József Kun, Kata Bölcskei and Zsuzsanna Helyes contributed equally to this work.

'Department of Pharmacology and Pharmacotherapy, Molecular

Pharmacology Research Group and Centre for Neuroscience, University of

Pécs Szentágothai Research Centre, University of Pécs Medical School, Szigeti

út 12, Pécs H-7624, Hungary

Full list of author information is available at the end of the article
}

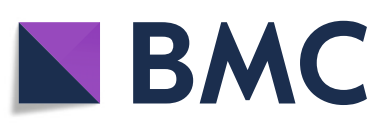

(- The Author(s). 2021 Open Access This article is licensed under a Creative Commons Attribution 4.0 International License, which permits use, sharing, adaptation, distribution and reproduction in any medium or format, as long as you give appropriate credit to the original author(s) and the source, provide a link to the Creative Commons licence, and indicate if changes were made. The images or other third party material in this article are included in the article's Creative Commons licence, unless indicated otherwise in a credit line to the material. If material is not included in the article's Creative Commons licence and your intended use is not permitted by statutory regulation or exceeds the permitted use, you will need to obtain permission directly from the copyright holder. To view a copy of this licence, visit http://creativecommons.org/licenses/by/4.0/. The Creative Commons Public Domain Dedication waiver (http://creativecommons.org/publicdomain/zero/1.0/) applies to the data made available in this article, unless otherwise stated in a credit line to the data. 


\section{Background}

Migraine is a primary headache condition characterized by moderate-to-severe unilateral pain of pulsating or throbbing quality and accompanying symptoms, such as nausea/vomiting or photo-/phonophobia. The headache can be triggered by a variety of factors such as alcohol, stress or hormonal changes [1]. There has been an ongoing debate about the precise pathophysiological mechanism of the disease, but the most accepted theory is that migraine is a disorder affecting the sensory processing of the brain [1]. However, the headache is most likely to be generated by the activation of the trigeminovascular system resulting in neurogenic vasodilation and inflammation of the meninges [2]. It is now evident that major contributors to headache development are the neuropeptides calcitonin gene-related peptide (CGRP) [3-5] and pituitary adenylate cyclase activating polypeptide (PACAP) [6-8]. Yet, the exact sequence of events during the phases of headache episode and the relative importance of central and peripheral mechanisms are still unclear. Except for the recently approved antiCGRP monoclonal antibodies, most of the preventive treatment is based on empirical observations rather than the understanding of the pathophysiology. Elucidating the pathophysiological mechanisms is crucial to identify the key mediators and determine novel therapeutic targets.

It is also accepted that migraine susceptibility has a genetic background $[9,10]$. However, most of the research using linkage, candidate gene- and genome-wide association studies (GWAS) provided limited results. GWAS have revealed susceptibility genes or loci implicating vascular and smooth muscle tissues, synaptic function, astrocyte-, microglia- and oligodendrocyte roles [11-13]. The few genomic next-generation sequencing studies mainly focused on certain candidate genes associated with glutamatergic neurotransmission and synaptic function/development, pain-sensing mechanisms, metalloproteinases and vascular metabolism [9]. Quite recently, the interaction between single nucleotide polymorphisms of three genes involved in synaptic transmission was also linked to migraine susceptibility [14]. None of the candidate genes could be conclusive as genetic biomarkers of the disease, each having small impact individually and limited predictive value [15]. The reason for this could be that genetic-environmental interactions play an important role in disease mechanisms in specific clinical conditions. Gene expression patterns associated with migraine reflect genetic and non-genetic effects and may inform of migraine susceptibility and outcome [16].

Recent results have pointed out that interactions between external stimuli and brain pathological processes may be reflected in peripheral tissues, such as the blood, which facilitates clinical research of several central nervous system diseases without invasive tissue sampling [16-18]. Differentially expressed genes have been described in peripheral whole blood of migraineurs by microarray or bead array $[19,20]$. More recently, whole blood next-generation RNA sequencing studies were also performed to compare healthy individuals and migraineurs. While the study by Gerring and coworkers revealed significant changes in immune function and cytokine signaling [21], another study by Kogelman and coworkers reported largely negative results [22].

To unveil pathways responsible for headache generation, a self-controlled study design to compare samples of headache (ictal) and headache-free (interictal) periods is also necessary. Since previous data show that the transcriptome of mononuclear blood cells is more closely correlated with the transcriptome of brain samples [18], RNA sequencing was performed from separated peripheral blood mononuclear cells (PBMCs) instead of the whole blood. We have also complemented the transcriptome analysis of peripheral blood mononuclear cells with a plasma metabolome analysis from simultaneously taken samples.

\section{Methods \\ Study design}

The study was approved by the National Public Health Center, Ministry of Human Capacities of Hungary (28324-5/2019/EÜIG). All study participants gave their written informed consent in accordance with the Declaration of Helsinki.

Episodic migraine patients (with or without aura) between the age of 20-65 years were included in the study. Migraineurs were selected in accordance with the criteria of the third edition of International Classification of Headache Disorders [23]: recurrent unilateral, pulsating headache, which manifests in moderate or severe intensity attacks lasting 4-72 h. Headache was aggravated by routine physical activity and associated with nausea and/or vomiting, as well as photophobia and phonophobia. Exclusion criteria for enrolment included chronic inflammatory diseases and depression.

Blood samples were drawn from migraine sufferers in an attack-free period and during an attack. The attackfree (interictal) sample was collected if the patient had no headache for at least $24 \mathrm{~h}$. For ictal samples, affected patients were asked not to start their usual attack treatment until the blood had been taken. There were no restrictions as regards food and drink intake. A detailed questionnaire was used to compile a homogeneous group of migraineurs concerning the features of their disease. Questions included the prophylactic or attack medication before sampling, number of attacks in the previous month, the time of the last attack, the 
beginning of the current attack, other known diseases, applied drugs and contraceptives, relation of migraine attacks to the menstrual cycle, the presence of allodynia, attack frequency, duration of migraine, severity of pain during attacks as measured on a visual analog scale, comorbidities with other chronic diseases, familial manifestation of migraine, regular sport activity and the time of the last meal were recorded.

Enrolment took place between September 2018 and December 2019. Thirty six female and 1 male subjects were recruited: 24 episodic migraine patients with or without aura and 13 healthy controls. Sample size was determined based on literature data [24, 25]. Healthy volunteers serving as controls were screened for nonreported/non-treated headaches.

\section{Sample collection}

Human blood (13 mL/person) was collected from cubital veins of migraineurs and healthy volunteers into ice-cold glass tubes containing ethylenediaminetetraacetic acid (EDTA) or citrate. For the transcriptomic measurements, the PBMCs were isolated by Ficoll-Paque PREM IUM (GE Healthcare, Budapest, Hungary) according to the manufacturer's instructions. Four $\mathrm{mL}$ of anticoagulant-treated blood and $4 \mathrm{~mL}$ phosphatebuffered saline (PBS) - EDTA solution were mixed in sterile centrifuge tubes. Next, the diluted blood samples were layered on $5 \mathrm{~mL}$ Ficoll-Paque PREMIUM and centrifuged $40 \mathrm{~min}$ at $400 \times \mathrm{g}, 20^{\circ} \mathrm{C}$. After the removal of the liquid phase, the PBMC layer was transferred into a new centrifuge tube, suspended with $6 \mathrm{~mL}$ PBS-EDTA solution and centrifuged $10 \mathrm{~min}$ at $500 \times \mathrm{g}, 20^{\circ} \mathrm{C}$. The supernatant was removed also and the pellet was suspended in $6 \mathrm{~mL}$ PBS-EDTA solution, followed by centrifugation $\left(10 \mathrm{~min}, 500 \times \mathrm{g}, 20^{\circ} \mathrm{C}\right)$. Liquid phase was removed and the cells were resuspended with $1 \mathrm{~mL}$ of TRI Reagent (Molecular Research Center, Cincinnati, OH, USA), transposed to Eppendorf tubes and stored at $-80^{\circ} \mathrm{C}$ until the gene expression investigations.

For the metabolomic measurements, the total human blood samples were centrifuged at $300 \times \mathrm{g}$ for $15 \mathrm{~min}$, twice at $2500 \times \mathrm{g}$ for $15 \mathrm{~min}$ and $18,000 \times \mathrm{g}$ for $90 \mathrm{~min}$ at $4{ }^{\circ} \mathrm{C}$. Plasma samples were stored at $-80^{\circ} \mathrm{C}$ until analysis. Samples showing signs of hemolysis were excluded.

\section{RNA extraction and quality control}

Isolation and purification of total RNA were carried out as previously described [26] using the phenolchloroform based TRI Reagent procedure (Molecular Research Center, Cincinnati, OH, USA), up to the step of acquiring the RNA-containing aqueous layer. The aqueous phase was mixed with an equal volume of absolute ethanol and was loaded into Zymo-Spin ${ }^{\text {Tx }}$ IICR Column. Direct-zol RNA MiniPrep kit (Zymo Research,
Irvine, CA, USA) was used according to the manufacturer's protocol including the optional on-column DNase digestion.

RNA concentrations were measured using Qubit 3.0 (Invitrogen, Carlsbad, CA, USA). The RNA quality was verified on TapeStation 4200 using RNA ScreenTape (Agilent Technologies, Santa Clara, CA, USA). We proceeded with high quality (RIN $>8$ ) RNA samples to library preparation.

\section{Illumina library preparation and sequencing}

The library for Illumina sequencing was prepared using NEBNext Ultra II Directional RNA Library Prep Kit for Illumina (NEB, Ipswitch, MA, USA). Briefly, mRNA was isolated from $500 \mathrm{ng}$ total RNA using NEBNext Poly(A) mRNA MAgnetic Isolation Module (NEB, Ipswitch, MA, USA). Thereafter, the mRNA was fragmented, end prepped and adapter-ligated. Finally, the library was amplified according to the manufacturer's instructions. The quality of the libraries was checked on 4200 TapeSation System using D1000 Screen Tape, the quantity was measured on Qubit 3.0. Illumina sequencing was performed on the NextSeq550 instrument (Illumina, San Diego, CA, USA) with $1 \times 76$ run configuration.

\section{Bioinformatics}

The sequencing reads were aligned against the Homo sapiens reference genome (GRCh37 Ensembl release) with STAR v2.5.3a [27]. After alignment, the reads were associated with known protein-coding genes and the number of reads aligned within each gene was counted using Rsubread package v2.0.0 [28]. Gene count data were normalized using the trimmed mean of $M$ values (TMM) normalization method of the edgeR R/Bioconductor package (v3.28, R v3.6.0, Bioconductor v3.9) [29]. For statistical testing the data were further log transformed using the voom approach [30] in the limma package [31]. Normalized counts were represented as transcripts per million (TPM) values. Fold change (FC) values between the compared groups resulting from linear modeling process and modified $\mathrm{t}$-test $p$-values were produced by the limma package. The Benjamini-Hochberg method was used to control the False Discovery Rate (FDR) and adjusted $p$-values were calculated by limma. In case of paired ictal and interictal samples the correlation between samples originating from the same patient was taken into account using the duplicateCorrelation function of limma. Functional analysis was performed to take into account the annotations of genes using the Gene Ontology (GO), Kyoto Encyclopedia of Genes and Genomes (KEGG), and Reactome databases. Detection of functional enrichment was performed in the differentially expressed gene list (DE list enrichment: Fisher's exact test for GO, hypergeometric test for 
KEGG and Reactome) and towards the top of the list when all genes have been ranked according to the evidence for being differentially expressed (ranked list enrichment: non-parametric Kolmogorov-Smirnov test for GO and KEGG, hypergeometric test for Reactome) applying the topGO v2.37.0, ReactomePA v1.30.0, gage v2.36.0 packages. The pathview package v1.26.0 [32] was used to visualize mapping data to KEGG pathways.

\section{Targeted metabolomic measurements}

Acetonitrile, formic acid, methanol and water, all LCMS grade, as well as ammonium acetate for HPLC and ethanol 96\% Ph. Eur. 9.0, were obtained from Molar Chemicals Kft. (Halásztelek, Hungary). The MxP Quant 500 Kit was purchased from Biocrates Life Sciences AG (Innsbruck, Austria). Phenyl isothiocyanate (PITC), phosphate buffered saline and pyridine were from Sigma Aldrich Kft (Budapest, Hungary). Phosphate buffered saline solution was prepared as per the recommendations of the manufacturer. $5 \mathrm{mmol} / \mathrm{L}$ ammonium acetate was prepared by adding $19 \mathrm{mg}$ ammonium acetate to $50 \mathrm{~mL}$ methanol.

Plasma samples were processed for analysis as recommended by the kit manufacturer. Briefly, after being allowed to thaw and equilibrate to room temperature, samples were homogenized. $10-\mu \mathrm{L}$ plasma aliquots, calibrators and controls were pipetted into the respective slots of a 96-well deep well reaction plate. The plate was dried for 30 min under nitrogen 5.0 (Messer Hungarogáz Kft., Budapest, Hungary). Derivatization was performed by adding $50 \mu \mathrm{L} 5 \%$ PITC prepared in a mixture of ethanol, pyridine and water $(1: 1: 1, \mathrm{v} / \mathrm{v})$ to each slot, covering and incubating the plate for $60 \mathrm{~min}$ at ambient temperature and, after removing the plastic lid, by drying for $60 \mathrm{~min}$ under nitrogen. $300 \mu \mathrm{L} 5 \mathrm{mmol} / \mathrm{L}$ ammonium acetate was subsequently added and the plate was shaken on an Allsheng MD-200 plate shaker at $450 \mathrm{rpm}$, ambient temperature, for $30 \mathrm{~min}$. Elution of the analytes into a 96-well deep-well collection plate was performed by applying positive pressure on a Phenomenex Presston manifold (Gen-Lab Kft., Budapest, Hungary). For runs including chromatographic separation, $150 \mu \mathrm{L}$ extract was pipetted to an LC collection plate and was diluted with $150 \mu \mathrm{L}$ water. For flow injection analysis, $10 \mu \mathrm{l} \mathrm{ex-}$ tract was transferred to a FIA collection plate and was diluted with $490 \mu \mathrm{L}$ mobile phase employed for the FIA runs.

Analysis was conducted on a Shimadzu Nexera XR high performance liquid chromatograph (Simkon Kft, Budapest, Hungary) coupled to a low-resolution Sciex Qtrap 5500 mass spectrometer equipped with an electrospray ionization unit and operated in the multiple reaction monitoring mode (Per-form Hungária Kft, Budapest, Hungary). Sciex Analyst v.1.6.3 software was used for instrument control and data acquisition. Peak review and analyte quantitation was done using the Biocrates MetIDQ ${ }^{\mathrm{TM}}$ (Nitrogen version) software as instructed by the kit manufacturer.

Samples were run using 4 different instrumental setups, with the liquid chromatographic separation of 106 metabolites, and the flow injection analysis of 524 metabolites. Both positive and negative ionization polarity was employed. Liquid chromatographic separation was performed using the stationary phase provided by the kit manufacturer and equipped with a precolumn Mixer (Biocrates A.G., Innsbruck, Austria). The mobile phases were water (A) and acetonitrile (B), both of which contained $0.2 \%$ formic acid. Analysis with positive ionization was carried out with an initial flow rate was $0.5 \mathrm{~mL} / \mathrm{min}$, then $0.6 \mathrm{~mL} / \mathrm{min}$ at $5.5 \mathrm{~min}$, then $8.0 \mathrm{~mL} /$ $\mathrm{min}$ at $7.0 \mathrm{~min}$, and, finally, $0.5 \mathrm{~mL} / \mathrm{min}$ at $7.5 \mathrm{~min}$. The following linear gradient program was applied (\% mobile phase B): initial, $0 \%$ for $0.25 \mathrm{~min}, 12 \%$ at $1 \mathrm{~min}, 17.5 \%$ at $3,0 \mathrm{~min}, 50 \%$ at $4.5 \mathrm{~min}$, and $100 \%$ at $5.5 \mathrm{~min}$. Analysis in the negative ionization mode was carried out with an initial flow rate of $0.5 \mathrm{~mL} / \mathrm{min}, 0.7 \mathrm{~mL} / \mathrm{min}$ at $4.5 \mathrm{~min}$, $0.8 \mathrm{~mL} / \mathrm{min}$ at $6.5 \mathrm{~min}$, and, finally, $0.5 \mathrm{~mL} / \mathrm{min}$ at 7.6 $\mathrm{min}$. The following linear gradient program was applied: initial, $0 \%$ for $0.25 \mathrm{~min}, 25 \%$ at $0.5 \mathrm{~min}, 50 \%$ at $3.0 \mathrm{~min}$, $75 \%$ at $4.0 \mathrm{~min}$, and $100 \%$ at $4.5 \mathrm{~min}$. The injection volume was $5 \mu \mathrm{L}$. The stationary phase was thermostatted at $50^{\circ} \mathrm{C}$. The general mass spectrometry settings in the positive and negative modes, respectively, were curtain gas, $45 \mathrm{~L} / \mathrm{min}$ and $20 \mathrm{~L} / \mathrm{min}$, collision gas, $9 \mathrm{~L} / \mathrm{min}$ and 8 $\mathrm{L} / \mathrm{min}$, ion spray voltage, $5500 \mathrm{~V}$ and $-4500 \mathrm{~V}$, ion source temperature, $500^{\circ} \mathrm{C}$ and $650^{\circ} \mathrm{C}$, ion source gas 1 , $60 \mathrm{~L} / \mathrm{min}$ and $40 \mathrm{~L} / \mathrm{min}$, and ion source gas $2,70 \mathrm{~L} / \mathrm{min}$ and $40 \mathrm{~L} / \mathrm{min}$. In the flow injection analysis mode, the mobile phase was prepared by adding 1 ampule FIA Mobile Phase Additive, supplied with the MxP Quant 500 kit, to $290 \mu \mathrm{L}$ methanol. The flow rate was $0.2 \mathrm{~mL} / \mathrm{min}$, the sample injection volume was $20 \mu \mathrm{L}$. Ionization was performed in the positive mode. In the 2 runs, respectively, curtain gas was $20 \mathrm{~L} / \mathrm{min}$ and $10 \mathrm{~L} / \mathrm{min}$, collision gas was $9 \mathrm{~L} / \mathrm{min}$, ion spray voltage was $5500 \mathrm{~V}$, ion source temperature was $200{ }^{\circ} \mathrm{C}$ and $350^{\circ} \mathrm{C}$, ion source gas 1 was set at $40 \mathrm{~L} / \mathrm{min}$ and $30 \mathrm{~L} / \mathrm{min}$, and ion source gas 2 was at $50 \mathrm{~L} / \mathrm{min}$ and $90 \mathrm{~L} / \mathrm{min}$. Analyte-specific mass spectrometry settings were provided by the kit manufacturer.

\section{Evaluation and statistical analysis of targeted metabolomic measurements}

The calculation of the concentrations of the metabolites evaluated in the targeted metabolomic measurements, as well as quality control assessment, was performed automatically by the Biocrates MetIDQ ${ }^{\mathrm{TM}}$ software. 42 metabolites, all determined in the liquid chromatography- 
mass spectrometry (LC-MS/MS) assay, were quantitated using 6-point calibration curves. Linear regression was applied using 1/concentration weights, except for dopamine (quadratic regression, 1/concentration weights). The determination coefficients of the fitted lines ranged between 0.9894-0.9999 (median: 0.9972). 64 metabolites, assayed using LC-MS/MS, were evaluated by comparing their peak areas to those of their respective internal standards dried onto each slot of the sample preparation plate in known concentrations. The quantitation of the 524 metabolites measured using flow injection analysistandem mass spectrometry (FIA-MS/MS) was performed automatically by the MetIDQ ${ }^{\mathrm{TM}}$ software employing algorithms not disclosed to the users of the Biocrates $\mathrm{MxP}^{\circ}$ Quant 500 kit. No data filtering or correction was applied in this phase of evaluation.

Raw metabolomic data treatment included cleaning of the background noise and unrelated ions through Molecular Feature Extraction (MFE) tool in Mass Hunter Qualitative Analysis Software (B.06.00, Agilent). Mass Profiler Professional (B.12.61, Agilent Technologies) software was used to perform quality assurance (QA) procedure and data filtration. QA procedure covered selection of metabolic features with good repeatability. To achieve this, only features detected in $>80 \%$ of the samples after QC, and samples having RSD $<30 \%$ were kept.

The differences between metabolomic profiles of the healthy controls and migraineurs (interictal and ictal) patients were studied. Homogeneity of variance and normality assumptions were studied using Levene's and Shapiro-Wilk tests respectively. Mean plasma concentrations of metabolites in 3 study groups were compared using one-way analysis of variance (ANOVA) test or Kruskal-Wallis test. For one-by-one comparisons, the ttest or Wilcoxon test were used. The statistical significance level was set at 0.05 for all two-sided tests and multivariate comparisons. All calculations were prepared in $\mathrm{R}$ ( $\mathrm{R}$ version 3.6.2).

\section{Results}

\section{Clinical characteristics of the patient population}

The baseline demographic and clinical characteristic of the studied population is presented in Table 1. The studied groups were well matched, without any betweengroup differences in age, and anthropometric measurements such as body mass index (BMI). Interictal blood samples were collected from all 24 migraine patients,

Table 1 Demographic and clinical characteristics of study participants. Mean \pm SD values are represented in the table

\begin{tabular}{|c|c|c|}
\hline Group & $\begin{array}{l}\text { Migraineurs with }(n=3) \text { and } \\
\text { without aura }(n=21)\end{array}$ & $\begin{array}{l}\text { Healthy control subjects } \\
(n=13)\end{array}$ \\
\hline Gender & female $n=23$ male $n=1$ & female $n=13$ \\
\hline Age (years) & $35 \pm 12.25$ & $35 \pm 4.96$ \\
\hline Body mass index (BMI) & $22.21 \pm 4.57$ & $24 \pm 3.47$ \\
\hline Last meal (hours ago) & $6.59 \pm 6.29$ & $3.69 \pm 5.32$ \\
\hline \multicolumn{3}{|l|}{ Co-morbidities and drugs of migraine patients } \\
\hline Known other diseases & yes $n=10$ no $n=14$ & \\
\hline Regular medication (except for attack therapy) & yes $n=7$ no $n=17$ & \\
\hline Hormonal contraceptives & yes $n=8$ no $n=16$ & \\
\hline Antimigraine prophylactic therapy & no $n=24$ & \\
\hline \multicolumn{3}{|l|}{ Clinical features of the headache } \\
\hline Disease duration (years) & $15 \pm 12$ & \\
\hline Attack frequency (attack/year) & $32 \pm 37.37$ & \\
\hline Visual analogue scale (VAS) & $7 \pm 1.44$ & \\
\hline Allodynia & yes $n=9$ no $n=15$ & \\
\hline Chronic pain & yes $n=3$ no $n=21$ & \\
\hline Menstruation-headache relationship & sensitive $n=10$ independent $n=13$ & \\
\hline Migraineurs in the family & yes $n=15$ no $n=9$ & \\
\hline Regular sport activity & yes $n=13$ no $n=11$ & \\
\hline \multicolumn{3}{|l|}{ Features of attacks before samplings } \\
\hline Number of attacks in the previous month & $3 \pm 3.31$ & \\
\hline Last attack before interictal blood sampling (days ago) & $16.58 \pm 28.35$ & \\
\hline Beginning of attack before ictal blood sampling (hours) & $17.91 \pm 29.47$ & \\
\hline
\end{tabular}


while ictal samples were obtained from 8 of them for self-controlled comparison.

\section{Transcriptome profile of PBMC samples}

Twenty out of 24 interictal blood samples were used for PBMC RNA sequencing.

In interictal PBMC samples compared to healthy ones, 163 genes were found to be differentially expressed with a fold change threshold of 1.5 and a $p$-value threshold of $0.05,135$ genes were upregulated and 28 were downregulated. Based on the average of fold change and $p$-value ranks (average rank), the interleukin (IL)-1 $\beta$ gene (IL1B) was implicated at the top of the differentially expressed (DE) gene list (Table S1). Other highly implicated genes include prostaglandin-endoperoxide synthase 2 (PTGS2) also known as cyclooxygenase 2 (COX2), tumor necrosis factor (TNF), and numerous chemokines, such as IL-8 (IL8).

In ictal PBMC samples, when compared to the interictal ones, 144 genes were differentially expressed (fold change: $1.3, p$-value: 0.05$), 64$ were upregulated, 80 downregulated. Heterogeneous nuclear ribonucleoprotein C like 1 (HNRNPCL1) was implicated most, along with olfactory receptor family 10 subfamily G member 2 (OR10G2) and interleukin 20 receptor subunit alpha (IL20RA), among others (Table S2). After FDR correction, two genes had adjusted $p$-values below 0.25 , heterogeneous nuclear ribonucleoprotein $C$ like 1 (HNRN PCL1) and cornichon family AMPA receptor auxiliary protein 3 (CNIH3).

In ictal PBMC samples compared to healthy samples, 131 genes were differentially expressed (fold change: 1.5 , $p$-value: 0.05$), 118$ were upregulated, 13 downregulated. Similarly to the interictal and healthy sample comparison, IL1B gene was implicated at the top of the differentially expressed gene list (Table S3). Other highly implicated genes include PTGS2, TNF, and numerous chemokines such as IL8.

When DE genes were visualized on heat maps (Figs. 1, $2,3)$, samples were clustered according to the original sample groups. Remarkably, the interictal group splits into two major and one minor subgroups based on gene expression patterns when compared to the healthy (Fig. 1) and ictal (Fig. 2) group.

Functional enrichment analysis of DE genes (DE list enrichment) and ranked list enrichment of all genes were carried out, which yielded statistically significant GO, KEGG and Reactome terms involved in PBMC cells of migraineurs (Tables 2, 3, 4).

In the interictal PBMC samples compared to healthy ones, cytokine and chemokine receptor binding, interleukin-10 (IL-10) signaling, as well as oxidative phosphorylation in the mitochondria were significantly affected.
In the ictal vs. interictal comparison, hormone and cytokine activity, oxidative phosphorylation, chemosensory receptors were implicated, among others.

In the ictal versus healthy comparison, IL-4, IL-10 and IL-13, as well as chemokine, growth factor and neuroactive ligand-receptor interactions were implicated.

Ranked list enrichment analysis of all genes statistically significantly implicated the metabolic pathway of oxidative phosphorylation (Tables 2, 3, 4) in the interictal PBMC samples when compared to the healthy control group (Fig. 4, upper panel) with a $p$-value of $8.82 \mathrm{E}-06$, as well as in the ictal samples in comparison with the interictal group (Fig. 4, lower panel) with a $p$-value of 0.000845 . Expression of most oxidative phosphorylation related genes on Fig. 4 were elevated in the interictal samples versus the healthy ones, while decreased in ictal samples during migraine attack when compared to the interictal groups. Expression of genes coding succinate dehydrogenase/fumarate reductase enzymes (SDHA, SDHB, SDHC, SDHD), for example, increased in the interictal samples versus the healthy ones, while decreased in ictal samples during migraine attack when compared to the interictal groups, albeit statistically non-significantly at the individual gene level.

\section{Metabolic alterations in the plasma of migraine patients}

Metabolomic measurements were performed on 14 interictal, 6 ictal and 6 healthy control plasma samples. During the migraine attack (ictal) spermine and spermidine levels were significantly reduced (Fig. 5A,B, pvalues: 0.021 and $<0.001$ ), in comparison to metabolite concentrations found in the samples from the attackfree period. Interestingly, the spermine/spermidine ratio was suppressed in migraineurs, but during headache the concentration ratio was restored to a healthy-like level (Fig. 5C, $p$-value: 0.014). Methionine sulfoxide levels significantly increased (Fig. 5D, $p$-values: 0.026) during the ictal phase, compared to the healthy group. Lactate and succinate levels were significantly elevated (Fig. 5E,F, $p$ values: 0.031 and 0.005 ) during the interictal phase when compared to healthy volunteers. Succinate concentration was also significantly higher ( $p$-value: 0.0022$)$ during the ictal phase compared to the healthy group, while aconitate was lower in the same comparison (Fig. 5G, $p$-value: 0.041).

\section{Discussion}

This is the first transcriptome analysis of PBMCs isolated from interictal and ictal samples of migraine patients in comparison with healthy controls suggesting the importance of inflammatory pathways and the potential contribution of various cytokines to migraine susceptibility. In addition to the inflammatory pathways, our results suggest potential implication of mitochondrial dysfunction in migraine. Moreover, significant 


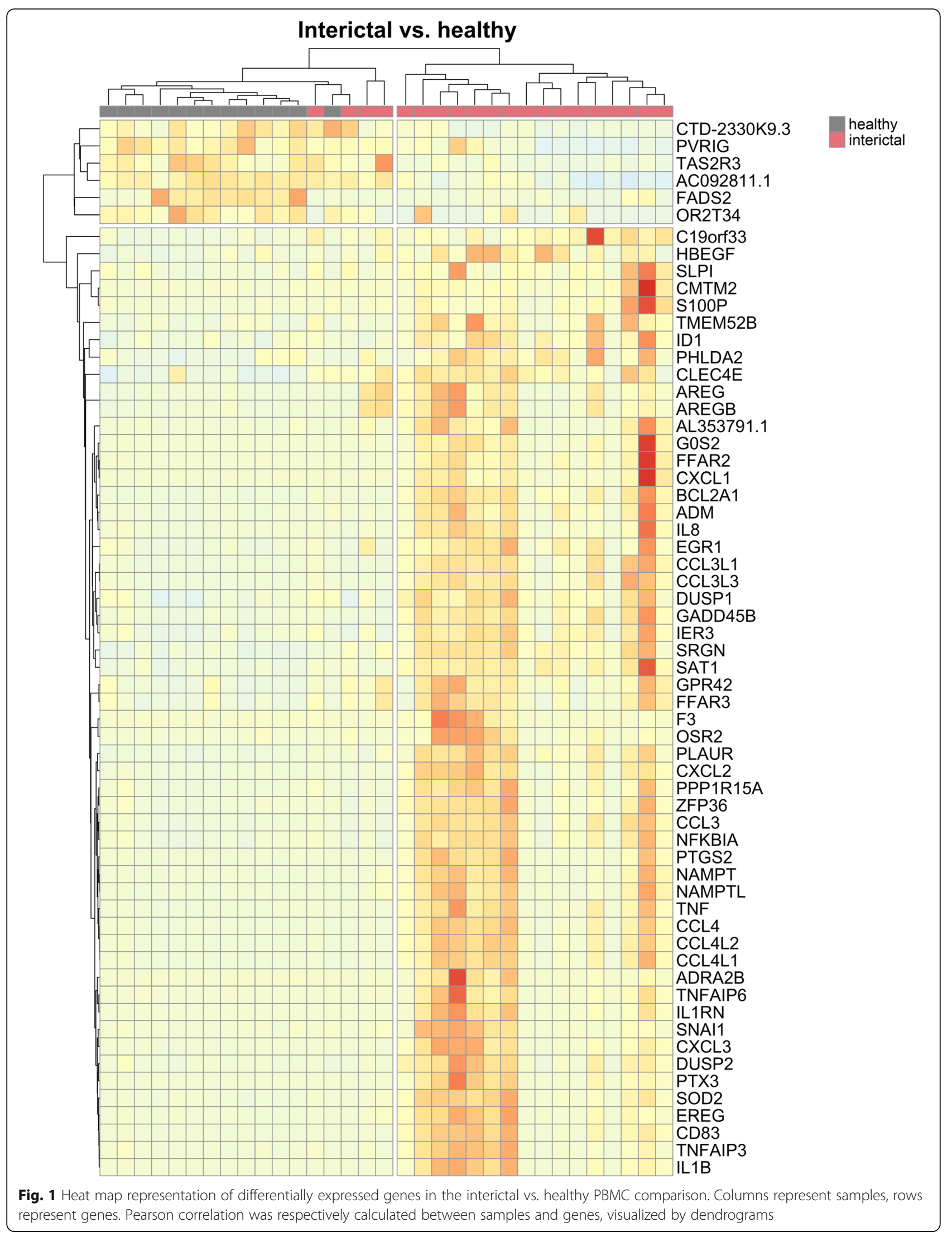




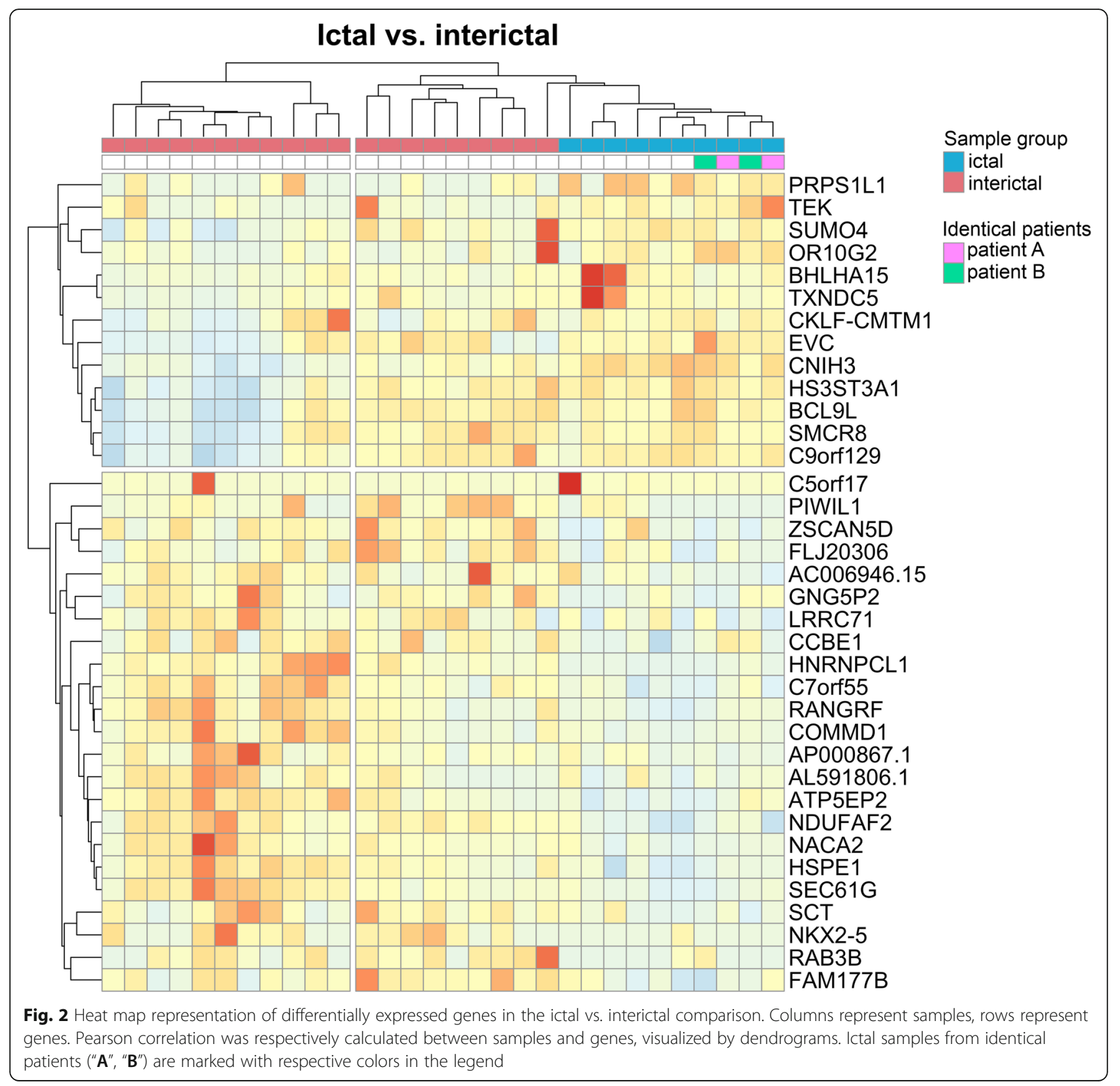

changes in some metabolites in the plasma also point to an alteration of mitochondrial electron transport chain or the citric acid cycle. There are two novel aspects of our analysis. On one hand, comparisons were made between healthy control samples to both the interictal and ictal samples of patients with the aim to identify both disease-specific and headache-specific alterations. On the other hand, instead of whole blood, we studied isolated mononuclear cells, the transcriptome of which had been reported to correlate better with the alterations in the brain [18]. Interestingly, significant gene expression and metabolite changes could be detected independently of headache episodes compared to healthy control samples which could be markers of migraine susceptibility, but not necessarily attack-specific.

A limitation of the study is that the RNA-based results are not confirmed by measuring the concentrations of the affected cytokines, but the results of the transcriptome analysis are in line with previous literature data which showed altered cytokine levels in migraine patients [33-36]. Our results showing immune pathway alterations are also in agreement with the findings of Gerring and coworkers' next-generation RNA sequencing study of the whole blood of migraine patients [21]. A further limitation is that only the ictal vs. interictal comparison yielded gene results after controlling for the 


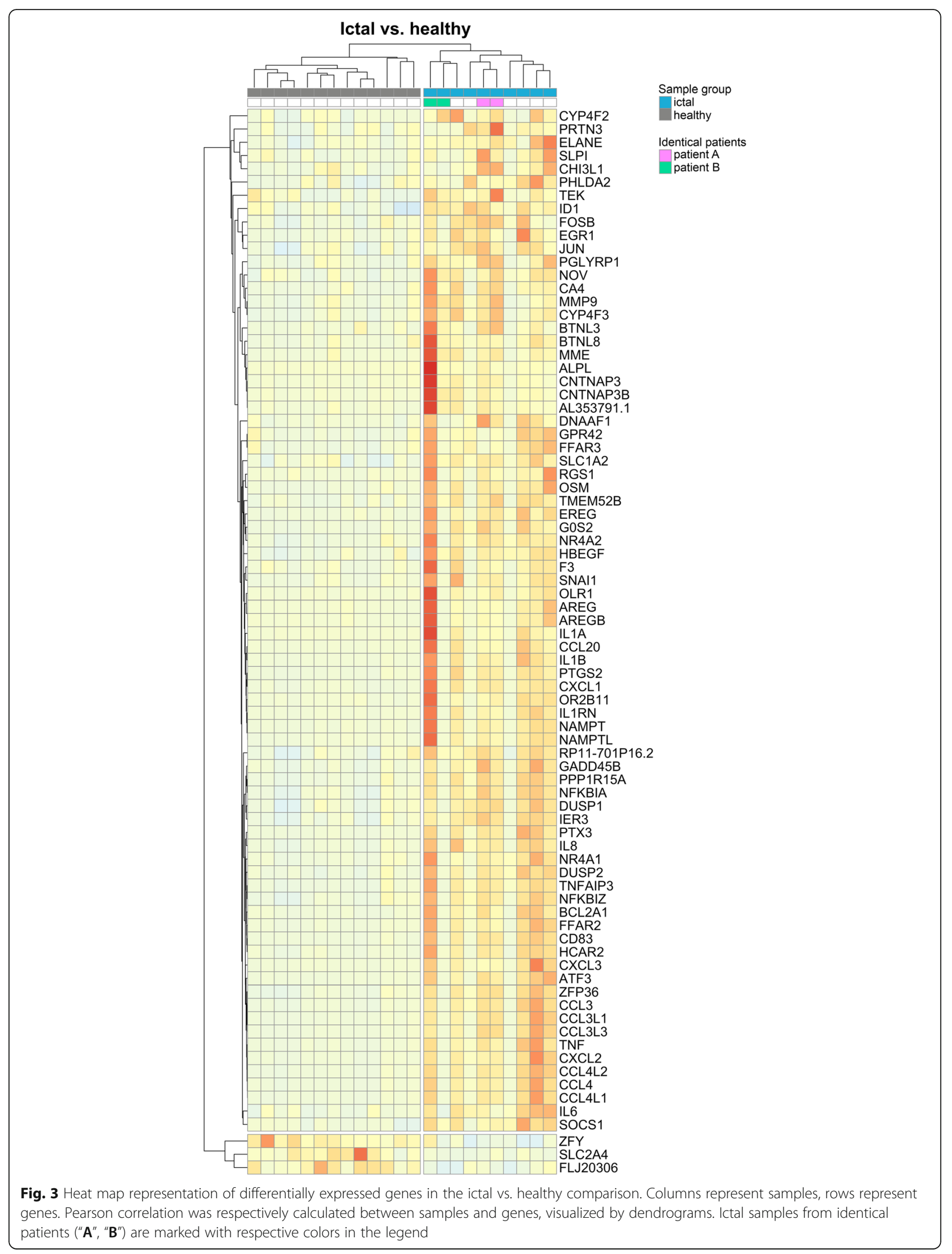


Table 2 Functional enrichment results of PBMC RNA-seq data of the interictal vs. healthy comparison. DE list enrichment: overrepresentation of functional terms in the differentially expressed gene list. Ranked list enrichment: enrichment of genes associated with a certain pathway towards the top of the ranked whole data. GO: gene ontology, BP: biological process, CC: cellular component, MF molecular function. KEGG: Kyoto Encyclopedia of Genes and Genomes. Annotated: number of genes associated with the given term. R: Reactome database. Significant: number of statistically significant associated with the given term. Expected: expected number of genes associated with the given term in the DE gene list. Gene ratio: ratio of number of genes in the DE list that overlap with genes associated with the given term, and the number of genes in the DE list which overlap with genes associated with all terms in the Reactome database. Bg ratio: ratio of the number of genes associated with the given term, and the total number of genes associated with Reactome terms

\begin{tabular}{|c|c|c|c|c|c|}
\hline \multicolumn{6}{|c|}{ Interictal vs. healthy } \\
\hline ID & DE list enrichment & Annotated & Significant & Expected & $p$-value \\
\hline GO:0006954 BP & inflammatory response & 625 & 31 & 6.03 & 2.60E-14 \\
\hline GO:0005126 MF & cytokine receptor binding & 210 & 14 & 1.89 & $6.10 \mathrm{E}-09$ \\
\hline \multirow[t]{2}{*}{ GO:0042379 MF } & chemokine receptor binding & 37 & 6 & 0.33 & 8.90E-07 \\
\hline & & GeneRatio & BgRatio & & $\mathrm{p}$-value \\
\hline \multirow[t]{2}{*}{ R-HSA-6783783 } & Interleukin-10 signaling & $11 / 96$ & $40 / 8821$ & & 2.60E-14 \\
\hline & Ranked list enrichment & Annotated & & & $\mathrm{p}$-value \\
\hline GO:0022900 BP & electron transport chain & 173 & & & 2.60E-14 \\
\hline GO:0005746 CC & mitochondrial respiratory chain & 82 & & & 2.17E-05 \\
\hline GO:0016684 MF & oxidoreductase activity, acting on peroxide as acceptor & 50 & & & 0.000016 \\
\hline KEGG 190 & Oxidative phosphorylation & 121 & & & $8.82 \mathrm{E}-06$ \\
\hline KEGG 4080 & Neuroactive ligand-receptor interaction & 157 & & & $2.28 \mathrm{E}-05$ \\
\hline
\end{tabular}

Table 3 Functional enrichment results of PBMC RNA-seq data of the ictal vs. interictal comparison. DE list enrichment: overrepresentation of functional terms in the differentially expressed gene list. Ranked list enrichment: enrichment of genes associated with a certain pathway towards the top of the ranked whole data. GO: gene ontology, BP: biological process, CC: cellular component, MF molecular function. KEGG: Kyoto Encyclopedia of Genes and Genomes. Annotated: number of genes associated with the given term. R: Reactome database. Significant: number of statistically significant associated with the given term. Expected: expected number of genes associated with the given term in the DE gene list. Gene ratio: ratio of number of genes in the DE list that overlap with genes associated with the given term, and the number of genes in the DE list which overlap with genes associated with all terms in the Reactome database. Bg ratio: ratio of the number of genes associated with the given term, and the total number of genes associated with Reactome terms

\begin{tabular}{|c|c|c|c|c|c|}
\hline \multicolumn{6}{|c|}{ Ictal vs. interictal } \\
\hline ID & DE list enrichment & Annotated & Significant & Expected & $p$-value \\
\hline GO:1902305 BP & regulation of sodium ion transmembrane transport & 55 & 4 & 0.39 & 2.60E-14 \\
\hline GO:0070382 CC & exocytic vesicle & 175 & 6 & 1.3 & 0.0019 \\
\hline GO:0005179 & hormone activity & 61 & 3 & 0.43 & 0.00924 \\
\hline \multirow[t]{2}{*}{ KEGG 4742} & Taste transduction & 35 & 2 & 0.219161 & 0.019843 \\
\hline & Ranked list enrichment & Annotated & & & p-value \\
\hline GO:0005746 CC & mitochondrial respiratory chain & 82 & & & 2.60E-14 \\
\hline GO:0005125 MF & cytokine activity & 149 & & & 0.000001 \\
\hline GO:0005179 MF & hormone activity & 61 & & & $6.95 \mathrm{E}-05$ \\
\hline GO:0030594 MF & neurotransmitter receptor activity & 57 & & & 0.000107 \\
\hline GO:0004984 MF & olfactory receptor activity & 44 & & & 0.000433 \\
\hline KEGG 4080 & Neuroactive ligand-receptor interaction & 157 & & & 9.04E-05 \\
\hline KEGG 190 & Oxidative phosphorylation & 121 & & & 0.000845 \\
\hline KEGG 140 & Steroid hormone biosynthesis & 36 & & & 0.00112 \\
\hline
\end{tabular}


Table 4 Functional enrichment results of PBMC RNA-seq data of the ictal vs. healthy comparison. DE list enrichment: overrepresentation of functional terms in the differentially expressed gene list. Ranked list enrichment: enrichment of genes associated with a certain pathway towards the top of the ranked whole data. GO: gene ontology, BP: biological process, CC: cellular component, MF molecular function. KEGG: Kyoto Encyclopedia of Genes and Genomes. Annotated: number of genes associated with the given term. R: Reactome database. Significant: number of statistically significant associated with the given term. Expected: expected number of genes associated with the given term in the DE gene list. Gene ratio: ratio of number of genes in the DE list that overlap with genes associated with the given term, and the number of genes in the DE list which overlap with genes associated with all terms in the Reactome database. Bg ratio: ratio of the number of genes associated with the given term, and the total number of genes associated with Reactome terms

\begin{tabular}{|c|c|c|c|c|c|}
\hline \multicolumn{6}{|l|}{ Ictal vs. healthy } \\
\hline ID & DE list enrichment & Annotated & Significant & Expected & $p$-value \\
\hline GO:1901700 BP & response to oxygen-containing compound & 1347 & 45 & 10.86 & $2.60 \mathrm{E}-14$ \\
\hline \multirow[t]{2}{*}{ GO:0070851 MF } & growth factor receptor binding & 105 & 7 & 0.83 & 0.000019 \\
\hline & & Gene ratio & Bg ratio & & $\mathrm{p}$-value \\
\hline R-HSA-6783783 & Interleukin-10 signaling & $10 / 84$ & $40 / 8821$ & & $2.60 \mathrm{E}-14$ \\
\hline R-HSA-6785807 & Interleukin-4 and Interleukin-13 signaling & $11 / 84$ & $98 / 8821$ & & $1.71 \mathrm{E}-09$ \\
\hline \multirow[t]{2}{*}{ R-HSA-179812 } & GRB2 events in EGFR signaling & $3 / 84$ & $11 / 8821$ & & 0.00013 \\
\hline & Ranked list enrichment & Annotated & & & p-value \\
\hline GO:0070098 BP & chemokine-mediated signaling pathway & 67 & & & 2.60E-14 \\
\hline KEGG 4080 & Neuroactive ligand-receptor interaction & 157 & & & $1.86 \mathrm{E}-14$ \\
\hline KEGG 4740 & Olfactory transduction & 63 & & & 0.000817 \\
\hline
\end{tabular}

false discovery rate. Migraine can have a prevalence of $20 \%$ of the population thus it can include a heterogeneous patient pool. In this regard our examination can be considered rather exploratory in nature with key results to be confirmed in a later study with a larger number of participants. Some similar migraine studies, however, have included patients in similar order of magnitude [22]. Controlling for FDR indeed reduces the number of false positive results but in turn increases false negatives. The cost of the latter is missing out on important discoveries [37]. Not having sufficient results after correction for multiple comparison also hinders finding associated biological functions. In a similar setting, examined the whole blood of migraineurs, Kogelman and colleagues performed correction for multiple testing and found two genes to be significantly differentially expressed [22]. They ran, however, functional enrichment analysis on the full non-corrected $\mathrm{DE}$ gene list, as well as co-expression network analysis on 5000 genes which is a multiple of the number of DE genes in their study. We carried out functional analysis by two approaches. One was DE list enrichment where potential false positive results at the gene level are expected to be randomly distributed among associated biological functions. Thus, significant biological terms supported by several DE genes are less likely to be false positive hits themselves. Our other method was ranked list enrichment that is not limited to the DE genes, hence it can circumvent the challenges of multiple comparison. The analysis considers the ranked list of all genes whose transcripts were detected.
While the vascular and neuronal origin of migraine has been debated for a long time, it is clear that there is an inflammatory component in the generation of the headache. NSAIDs are partially effective to relieve the headache pointing to the contribution of prostaglandins to nociceptor sensitization. Activation of resident mast cells in the meninges and release of proinflammatory cytokines such as IL-1 $\beta$, IL- 6 , TNF- $\alpha$ and several chemokines have been proposed to play major roles in the progression of migraine headache (Fig. 6) [38, 39]. Moreover, cytokine release by glial cells is also likely to contribute to migraine pathomechanism, as it was shown that cortical spreading depression can result in inflammosome activation in the brain parenchyma, as well [40]. In our study upregulation of several cytokines, as well as COX-2 were detected in PBMCs of migraine patients in both interictal and ictal samples compared to healthy controls pointing to a systemic change of immune functions. These data are in line with previous reports of elevated plasma levels of various proinflammatory cytokines like IL-1, IL-6 [33], TNF $\alpha$ [34], IL-8, CCL3 and CCL5 [41, 42] and C-reactive proteins (CRP) $[43,44]$. Moreover, during attacks, the concentration of IL-1 $\beta$, IL-6, IL-8, IL-10 and TNF- $\alpha$ were further increased $[35,36]$. Cytokines are fundamental regulators of inflammatory and immune reactions, and several of them have been directly implicated in pain sensitization by acting both on peripheral nociceptive nerve terminals and sensory ganglia, as well as participating in central sensitization. The pro-nociceptive role 

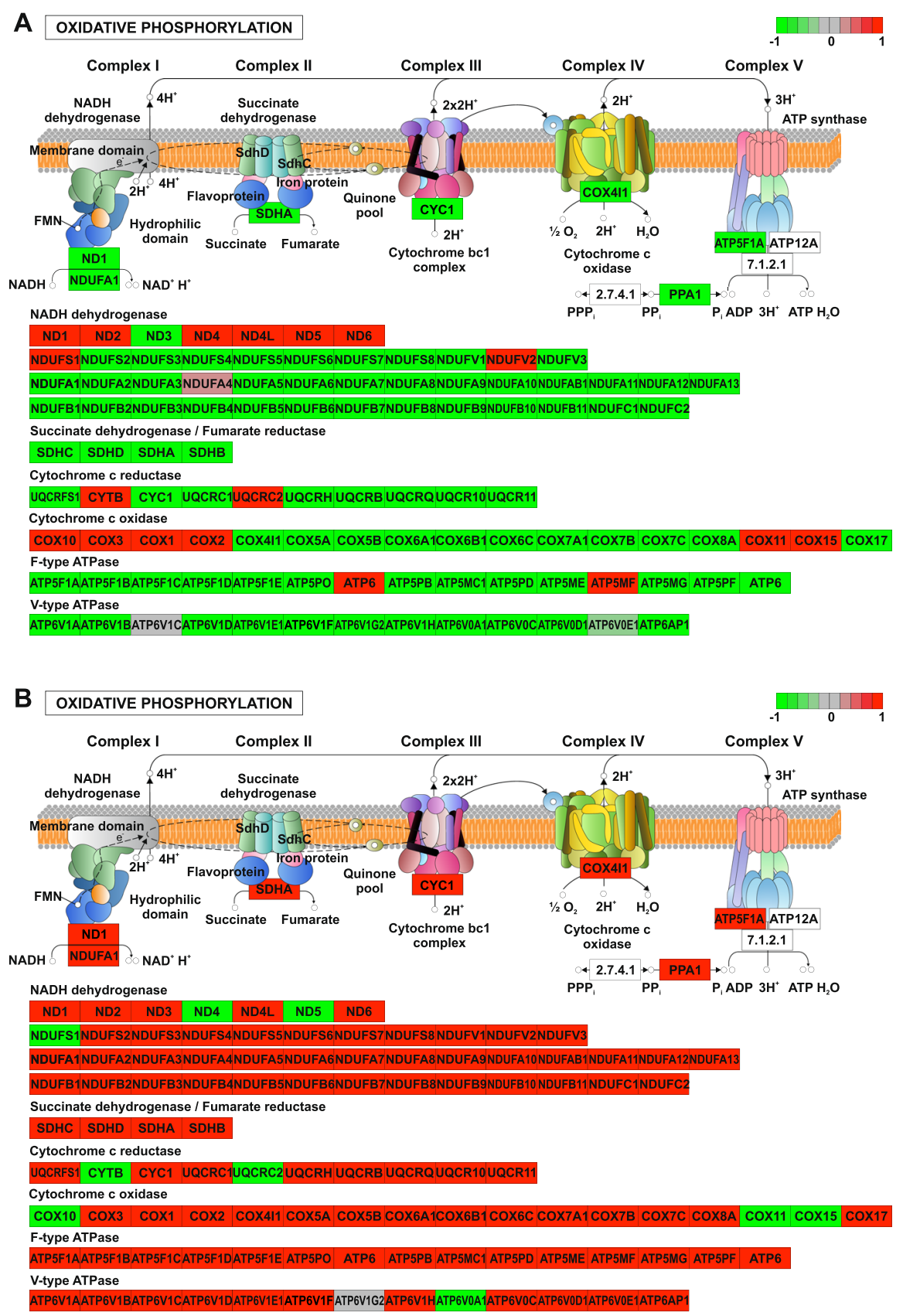

Fig. 4 Oxidative phosphorylation was implicated as a significantly altered metabolic pathway based on the ranked list enrichment analysis of all genes whose transcripts were detected from PBMC samples. Results of the analysis between ictal vs. interictal (upper panel) and interictal vs. healthy (lower panel) samples are shown. All detected genes are mapped to the pathway map. Original figure was rendered by Pathview

of IL-1 $\beta$ or TNF $\alpha$ in both peripheral and central pain mechanisms is well characterized [45-48]. Their potential contribution to headaches was supported by data that application of IL-1 $\beta$ or TNF $\alpha$ on rat dura resulted in activation and sensitization of meningeal nociceptors $[49,50]$. Other cytokines from our top DE gene list, such as CXCL1, 2 or 3 (all ligands of the CXCR2 receptor), have also been shown to be pro-nociceptive [51].
Intrathecal administration of CXCL1, 2 or 3 produced hyperalgesia in mice [52]. These chemokines have also been implicated in neuropathic pain [52-54] and nociceptive sensitization after traumatic brain injury $[55,56]$. CXCL1 in the synovial fluid of osteoarthritis patients correlated with the severity of pain [57]. Furthermore, significantly upregulated genes in our study include amphiregulin and epiregulin, which are epidermal 

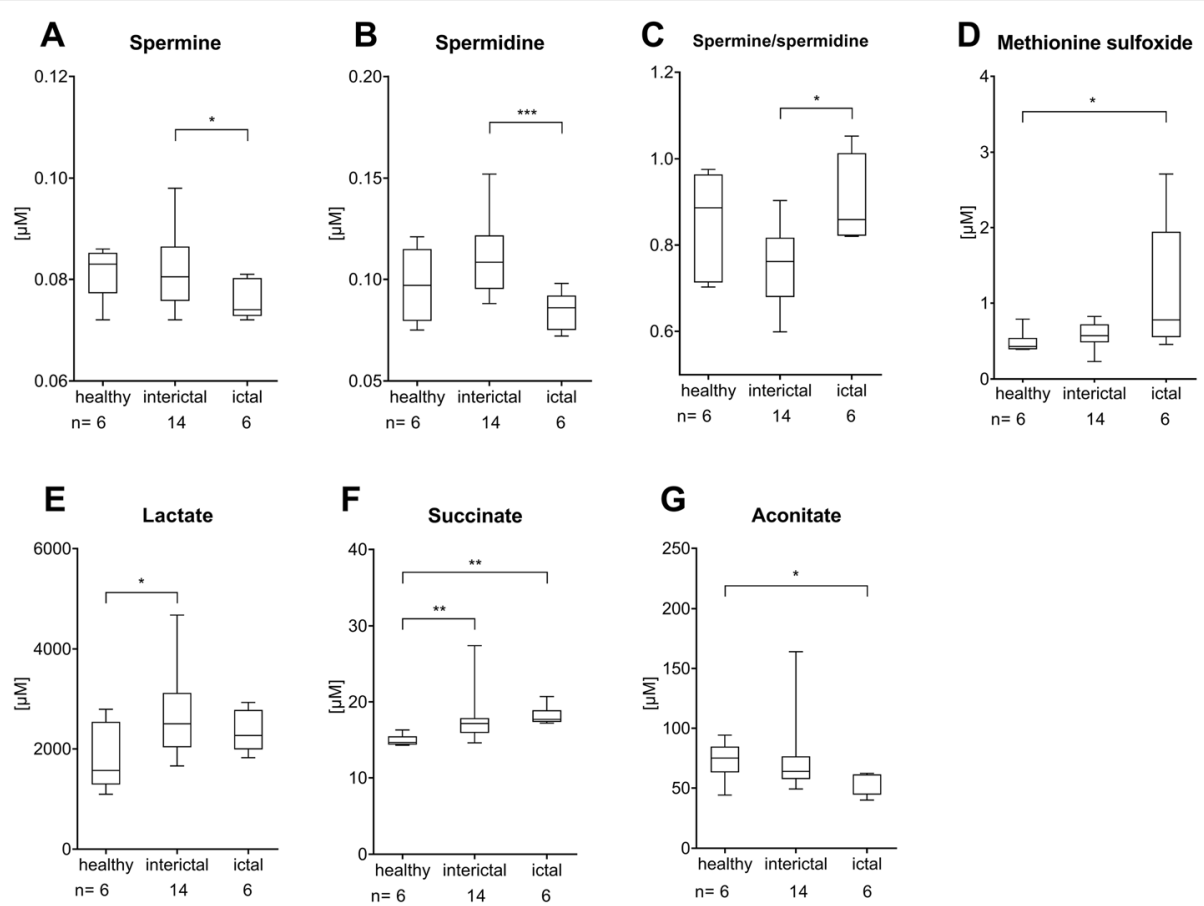

Fig. 5 Differences in plasma metabolomic profiles of healthy controls and migraineurs (interictal and ictal) for different classes of compounds: $(\mathbf{A}, \mathbf{B}, \mathbf{C})$ biogenic amines; (D) amino acid-related; and (E, F, G) carboxylic acids. Plasma concentrations of different metabolites are compared between groups and are considered significantly different when $p \leq 0.05$. Asterisks denote significant differences $\left({ }^{*} p \leq 0.05,{ }^{* *} p \leq 0.01\right.$, ${ }^{* * *} p \leq 0.001$ ), as analyzed by one-way analysis of variance (ANOVA) for A, B, C, E and Kruskal-Wallis test for D, F, G samples

growth factor receptor (EGFR) ligands. These proteins have been implicated in tumor growth; however, a role in inflammation has also been described $[58,59]$. Epiregulin, but not amphiregulin has been shown to be pronociceptive in mice, and EGFR inhibitors were analgesic in a variety of animal models of chronic pain [60]. $\mathrm{Hu}-$ man data indicate that both amphiregulin and epiregulin expressions were higher in bone marrow-derived mononuclear cells of rheumatoid arthritis patients and increased expression of amphiregulin was also detected in PBMCs and synovial tissues [61].

Recently, the metabolic alterations in migraine have also been highlighted [62, 63] and a meta-analysis pointed to the importance of oxidative and nitrosative stress [64]. A possible link between mitochondrial dysfunction and neuroinflammation is the demonstration of NLRP3 inflammosome activation by mitochondrial reactive oxygen species which was postulated to participate in several CNS disorders including migraine [40]. Several lines of evidence demonstrate that in migraineurs there is an imbalance between energy requirement and supply of the brain $[62,63]$ and it has been hypothesized that the attack can be a consequence of an adaptive response to restore energy homeostasis. Impaired mitochondrial energy production has been detected in the brain and skeletal muscle of migraine patients during attacks, but also even interictally [65-68]. Moreover, it has also been raised that migraine triggers act as promoters of oxidative stress $[69,70]$ and various studies have consistently reported elevated levels of oxidative stress markers or a deficit of antioxidant mechanisms $[62,64]$. Activities of various mitochondrial enzymes have been found to be altered in the platelets of migraine patients [71, 72].

In connection with the pathways identified with the PBMC transcriptome analysis, we have detected significant differences in several metabolites reflecting changes in mitochondrial function. These results provide a complementary viewpoint to a $\mathrm{DE}$ centric interpretation of our RNA-seq results. Lactate levels were increased in interictal, but not the ictal samples compared to the healthy plasma, while succinate levels were increased in both sets of migraine samples. Another intermediate metabolite of the citric acid cycle, aconitate was slightly decreased in parallel. Previous studies have already detected similar increases in plasma lactate and pyruvate levels [73], and it has also been reported that in migraine patients lactate levels rose higher upon exercise [74]. There are also data on increased lactate levels in some brain areas, although these were only detected in migraineurs with aura [62]. Abnormal "astrocyte-to-neuron lactate shuttle" has been considered to be behind the altered lactate metabolism, where astrocytes, through the end product of anaerobic glycolysis (lactate), provide 


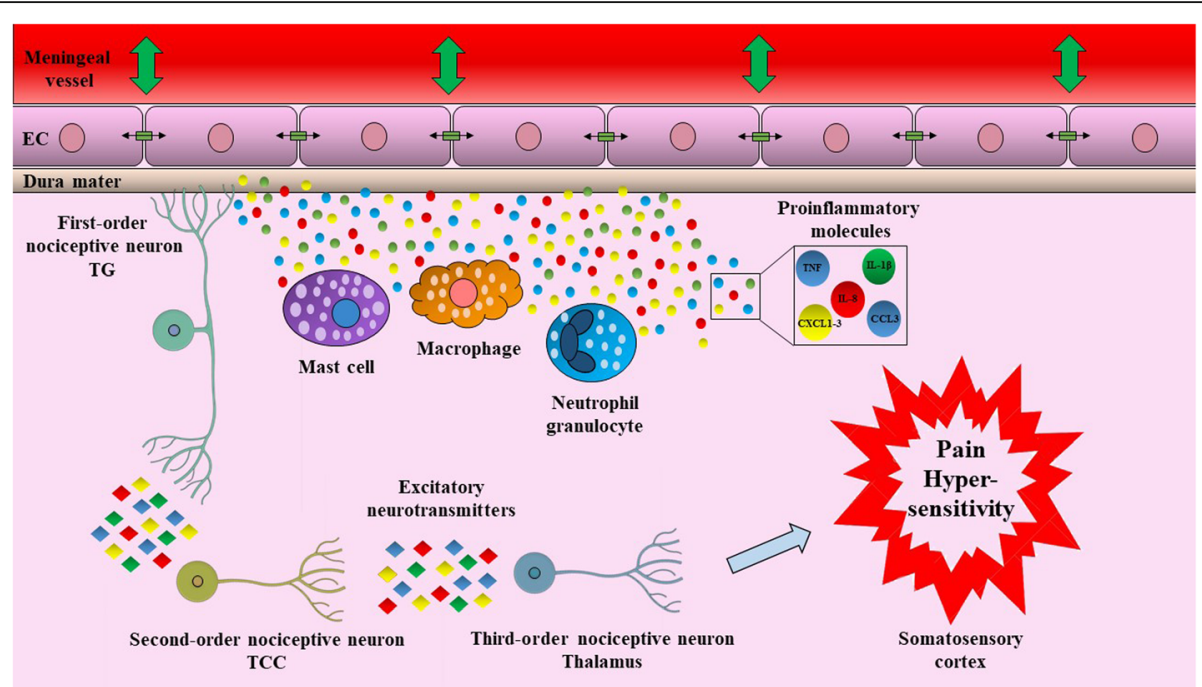

Fig. 6 Hypothetical contribution of inflammatory cytokines in migraine headache. Activation of immune cells alters the trigeminovascular microenvironment via the release of inflammatory molecules, such as cytokines and chemokines. These molecules cause vasodilation of dural vasculature and influence tight junction between endothelial cells. Activated trigeminal neurons transmit signals for the higher brain regions, which result in pain and hypersensitivity. CCL3: C-C motif ligand 3, CXCL1: C-X-C motif chemokine ligand 1, CXCL2: C-X-C motif chemokine ligand 2, CXCL3: C-X-C motif chemokine ligand 3, EC: endothelial cell, IL-1ß: interleukin-1ß, IL-8: interleukin-8, TCC: trigeminocervical complex, TNF: tumor necrosis factor, TG: trigeminal ganglion

energy to the activated neurons [75]. Regarding succinate, elevated levels were linked to a worse metabolic state in obese patients [76] and increased succinate concentrations have also been detected in the plasma of severely injured patients [77]. Also, succinate has been suggested to be a metabolic indicator of sepsis and mitochondrial dysfunction [78], with altered tissue concentrations under ischemia and inflammation [79-81]. However, novel data also indicate that succinate released for activated macrophages can act as a pro-inflammatory local mediator $[80,82]$, which could be another link between metabolic alterations in the plasma and inflammatory reactions. Other significantly changed metabolites include the polyamines spermine and spermidine and the oxidized metabolite of methionine, MetSO. Spermine and spermidine are involved in multiple cellular processes including the regulation of transcription and translation, alteration of ion channel and receptor function, and regulation of nitric oxide synthase. They act as scavengers of reactive oxygen radicals, thus represent important elements of normal mitochondrial functions. Polyamines also take part in protection from oxidative damage by stimulating the synthesis of superoxide dismutase, heat shock proteins and cell cycle regulators [83-89]. However, it has been described that overproduction or over-intake of these polyamines might contribute to cellular damage by oxidative mechanisms. In the brain, they might play a role in gap junction permeability and neuronal hyperexcitability under pathological conditions. Interestingly, spermine also can regulate the activity of glutamate-receptors, TRPV1 channels, and glial Kir4.1 channels [90-94]. Methionine, due to exposure to reactive oxygen species (ROS), oxidizes to MetSO. This procedure can be reversed by the methionine sulfoxide reductase (Msr) [95]. Currently, a correlation has been suggested between the increment in MetSO plasma levels and Alzheimer's disease progression [96]. Besides, altered Msr system function and MetSO accumulation have been proposed to be biomarkers of aging [97-99]. However, to our knowledge, this is the first study to link increased plasma levels of MetSO to migraine-related processes.

\section{Conclusions}

In summary, our results suggest that enhanced immune cell activity and oxidative stress generation play important roles in migraine susceptibility and headachegeneration. Detection of altered gene expressions and metabolite levels in the peripheral blood point to the systemic nature of the disease. Our study also indicates that drugs targeting cytokines or reducing oxidative stress might be valuable for migraine treatment or prophylaxis.

\section{Abbreviations}

PBMC: Peripheral blood mononuclear cells; CGRP: Calcitonin gene-related peptide; PACAP: Pituitary adenylate cyclase activating polypeptide;

GWAS: Genome-wide association studies; EDTA: Ethylenediaminetetraacetic acid; PBS: Phosphate-buffered saline; FC: Fold change; FDR: False discovery rate; GO: Gene ontology; KEGG: Kyoto encyclopedia of genes and genomes; DE: Differentially expressed; PITC: Phenyl isothiocyanate; LC-MS/MS: Liquid chromatography-mass spectrometry; FIA-MS/MS: Flow injection analysis- 
tandem mass spectrometry; QA: Quality assurance; QC: Quality control; ANOVA: Analysis of variance; BMI: Body mass index; L: Interleukin; PTGS2: Prostaglandin-endoperoxide synthase 2; COX2: Cyclooxygenase 2; TNF: Tumor necrosis factor; CRP: C-reactive protein; EGFR: Epidermal growth factor receptor; ROS: Reactive oxygen species

\section{Supplementary Information}

The online version contains supplementary material available at https:/doi. org/10.1186/s10194-021-01285-9.

Additional file 1: Table S1. Top 20 differentially expressed genes in PBMCs comparing interictal and healthy control samples. Avg rank: average rank of $p$-value and fold change ranks; ID: Ensembl gene identifier. Table S2. Top 20 differentially expressed genes in PBMCs comparing interictal and ictal samples. Avg rank: average rank of $p$-value and fold change ranks; ID: Ensembl gene identifier. Table S3. Top 20 differentially expressed genes in PBMCs comparing ictal and healthy control samples. Avg rank: average rank of $p$-value and fold change ranks; ID: Ensembl gene identifier.

\section{Acknowledgments}

Not applicable.

\section{Authors' contributions}

Conceptualization: Z.H., K.B., J.K., A.G, L.V., J.T. Formal Analysis: J.K., R.H., W.B., A.G, G.B.K. Investigation: A.T., T.K., J.K., B.T., U.P., K.K., R.F., G.B.K. Resources: T.K., B.T., L.V, J.T., A.G., B.V., Z.H. Writing - Original Draft Preparation: A.T., T.K., J.K., U.P., W.B., G.B.K., K.B., Z.H. Writing - Review and Editing: A.T., T.K., J.K., P.U., W.B., R.H., R.F., K.K., B.V., G.B.K, A.G., B.T., J.T., L.V., K.B., Z.H. Visualization: A.T., T.K., J.K., W.B. Supervision: Z.H., K.B., A.G, L.V., J.T., V.B. Funding Acquisition: Z.H. K.B., A.G., L.V., J.T. The author(s) read and approved the final manuscript.

\section{Funding}

This research was supported by National Brain Research Program 2017-1.2.1NKP-2017-00002 (NAP-2; Chronic Pain Research Group), Gazdaságfejlesztési és Innovációs Operatív Program (Economy Development and Innovation Operative Programme) (GINOP)-2.3.2-15-2016-00050 (Peptidergic Signaling in Health and Disease; PEPSYS), GINOP 2.3.2-15-2016-0034, Emberi Erőforrás Operatív Program (Human Resource Operative Programme) (EFOP) 3.6.2-162017-00008 (2017-2019), EFOP-3.6.1-16-2016-00004, TUDFO/47138-1/2019ITM and National Research Development and Innovation Office grant OTKA FK132587. A.G. and J.K. were supported by the grants GINOP-2.3.4-15-202000010, GINOP-2.3.1-20-2020-00001 and Educating Experts of the Future: Developing Bioinformatics and Biostatistics competencies of European Biomedical Students (BECOMING, 2019-1-HU01-KA203-061251). Bioinformatics infrastructure was supported by ELIXIR Hungary (http://elixir-hungary.org/). The funders had no role in study design, data collection and analysis, decision to publish, or preparation of the manuscript.

\section{Availability of data and materials}

The RNA-Seq dataset supporting the conclusions of this article is available in the European Nucleotide Archive (https://www.ebi.ac.uk/ena), under accession number PRJEB40032.

\section{Declarations}

\section{Ethics approval and consent to participate}

The study was approved by the National Public Health Center, Ministry of Human Capacities of Hungary (28324-5/2019/EÜIG). All study participants gave their written informed consent in accordance with the Declaration of Helsinki.

\section{Consent for publication}

Not applicable.

\section{Competing interests}

The authors disclose no conflicts of interest.

\section{Author details}

'Department of Pharmacology and Pharmacotherapy, Molecular Pharmacology Research Group and Centre for Neuroscience, University of Pécs Szentágothai Research Centre, University of Pécs Medical School, Szigeti út 12, Pécs H-7624, Hungary. ${ }^{2}$ Department of Neurology, Interdisciplinary Excellence Centre, Faculty of Medicine, Albert Szent-Györgyi Clinical Center, University of Szeged, Semmelweis u. 6, Szeged H-6725, Hungary. ${ }^{3}$ MTA-SZTE Neuroscience Research Group, University of Szeged, Semmelweis u. 6, Szeged H-6725, Hungary. ${ }^{4}$ Faculty of Health Sciences and Social Studies, University of Szeged, Temesvári krt. 31, Szeged H-6726, Hungary. ${ }^{5}$ Szentágothai Research Centre, Bioinformatics Research Group, Genomics and Bioinformatics Core Facility, University of Pécs, Ifjúság útja 20, Pécs H-7624, Hungary. ${ }^{6}$ Department of Laboratory Medicine, Semmelweis University, Nagyvárad tér 4, Budapest H-1089, Hungary.

Received: 14 May 2021 Accepted: 1 July 2021

Published online: 06 October 2021

\section{References}

1. Goadsby PJ, Holland PR, Martins-Oliveira M, Hoffmann J, Schankin C, Akerman S (2017) Pathophysiology of migraine: A disorder of sensory processing. Physiol Rev 97(2):553-622. https://doi.org/10.1152/physrev. 00034.2015

2. Olesen J, Burstein R, Ashina M, Tfelt-Hansen P (2009) Origin of pain in migraine: evidence for peripheral sensitisation. Lancet Neurol 8(7):679-690. https://doi.org/10.1016/S1474-4422(09)70090-0

3. Tepper SJ (2018) History and review of anti-calcitonin gene-related peptide (CGRP) therapies: from translational research to treatment. Headache. 58(Suppl 3):238-275. https://doi.org/10.1111/head.13379

4. Charles A, Pozo-Rosich P (2019) Targeting calcitonin gene-related peptide: a new era in migraine therapy. Lancet 394(10210):1765-1774. https://doi.org/1 0.1016/S0140-6736(19)32504-8

5. Hargreaves R, Olesen J (2019) Calcitonin gene-related peptide modulators the history and renaissance of a new migraine drug class. Headache. 59(6): 951-970. https://doi.org/10.1111/head.13510

6. Amin FM, Asghar MS, Guo S, Hougaard A, Hansen AE, Schytz HW, van der Geest RJ, de Koning PJH, Larsson HBW, Olesen J, Ashina M (2012) Headache and prolonged dilatation of the middle meningeal artery by PACAP38 in healthy volunteers. Cephalalgia. 32(2):140-149. https://doi.org/10.1177/ 0333102411431333

7. Schytz HW, Birk S, Wienecke T, Kruuse C, Olesen J, Ashina M (2009) PACA P38 induces migraine-like attacks in patients with migraine without aura. Brain. 132(1):16-25. https://doi.org/10.1093/brain/awn307

8. Tuka B, Helyes Z, Markovics A, Bagoly T, Szolcsányi J, Szabó N, Tóth E, Kincses ZT, Vécsei L, Tajti J (2013) Alterations in PACAP-38-like immunoreactivity in the plasma during ictal and interictal periods of migraine patients. Cephalalgia. 33(13):1085-1095. https://doi.org/10.1177/ 0333102413483931

9. Tolner EA, Houben T, Terwindt GM, de Vries B, Ferrari MD, van den Maagdenberg AM (2015) From migraine genes to mechanisms. Pain 156(Suppl 1):S64-74. https://doi.org/10.1097/01.jpain.0000460346.00213.16

10. Sutherland $H G$, Albury $C L$, Griffiths $L R$ (2019) Advances in genetics of migraine. J Headache Pain 20(1):72. https://doi.org/10.1186/s10194-019-101 7-9

11. Freilinger T, Anttila V, de Vries B, Malik R, Kallela M, Terwindt GM et al (2012) Genome-wide association analysis identifies susceptibility loci for migraine without aura. Nat Genet 44(7):777-782. https://doi.org/10.1038/ng.2307

12. Gormley P, Anttila V, Winsvold BS, Palta P, Esko T, Pers TH et al (2016) Metaanalysis of 375,000 individuals identifies 38 susceptibility loci for migraine. Nat Genet 48(8):856-866. https://doi.org/10.1038/ng.3598

13. Eising $E$, de Leeuw C, Min JL, Anttila V, Verheijen MH, Terwindt GM et al (2016) Involvement of astrocyte and oligodendrocyte gene sets in migraine. Cephalalgia. 36(7):640-647. https://doi.org/10.1177/0333102415618614

14. Alves-Ferreira M, Quintas M, Sequeiros J, Sousa A, Pereira-Monteiro J, Alonso I, Neto JL, Lemos C (2021) A genetic interaction of NRXN2 with GABRE, SYT1 and CASK in migraine patients: a case-control study. J Headache Pain. 22(1): 57. https://doi.org/10.1186/s10194-021-01266-y

15. Di Lorenzo C, Santorelli FM, van den Maagdenberg AMJM (2015) Genetics of headache. In: Ashina M, Geppetti P (eds) Pathophysiology of headaches: from molecule to man. Springer International Publishing, Cham, pp 83-99. https://doi.org/10.1007/978-3-319-15621-7_4 
16. Gerring Z, Rodriguez-Acevedo AJ, Powell JE, Griffiths LR, Montgomery GW, Nyholt DR (2016) Blood gene expression studies in migraine: potential and caveats. Cephalalgia. 36(7):669-678. https://doi.org/10.1177/0333102416628463

17. Sullivan PF, Fan C, Perou CM (2006) Evaluating the comparability of gene expression in blood and brain. Am J Med Genet B Neuropsychiatr Genet 141B(3):261-268. https://doi.org/10.1002/ajmg.b.30272

18. Rollins B, Martin MV, Morgan L, Vawter MP (2010) Analysis of whole genome biomarker expression in blood and brain. Am J Med Genet B Neuropsychiatr Genet 153B:919-936

19. Hershey AD, Tang Y, Powers SW, Kabbouche MA, Gilbert DL, Glauser TA Sharp FR (2004) Genomic abnormalities in patients with migraine and chronic migraine: preliminary blood gene expression suggests platelet abnormalities. Headache. 44(10):994-1004. https://doi.org/10.1111/j.1526-461 0.2004.04193.x

20. Hershey A, Horn P, Kabbouche M, O'Brien H, Powers S (2012) Genomic expression patterns in Menstrually-related migraine in adolescents. Headache. 52(1):68-79. https://doi.org/10.1111/j.1526-4610.2011.02049.x

21. Gerring ZF, Powell JE, Montgomery GW, Nyholt DR (2018) Genome-wide analysis of blood gene expression in migraine implicates immuneinflammatory pathways. Cephalalgia. 38(2):292-303. https://doi.org/10.1177/ 0333102416686769

22. Kogelman LJ, Falkenberg K, Halldorsson GH, Poulsen LU, Worm J, Ingason A et al (2019) Comparing migraine with and without aura to healthy controls using RNA sequencing. Cephalalgia. 39(11):1435-1444. https://doi.org/10.11 77/0333102419851812

23. Headache Classification Committee of the International HeadacheSociety (IHS) (2018) The International Classification of Headache Disorders, vol 38 , 3rd edn. Cephalalgia, pp 1-211. https://doi.org/10.1177/0333102417738202

24. Gardiner IM, Ahmed F, Steiner TJ, McBain A, Kennard C, de Belleroche J (1998) A study of adaptive responses in cell signaling in migraine and clusterheadache: correlations between headache type and changes in gene expression. Cephalalgia 18:192-196. https://doi.org/10.1046/j.1468-2982.1 998.1804192.x

25. Plummer PN, Colson NJ, Lewohl JM, MacKay RK, Fernandez F, Haupt LM Griffiths LR (2011) Significant differences in gene expression of GABA receptors inperipheral blood leukocytes of migraineurs. Gene 490:32-36. https://doi.org/10.1016/j.gene.2011.08.031

26. Aczél T, Kun J, Szőke É, Rauch T, Junttila S, Gyenesei A et al (2018) Transcriptional Alterations in the Trigeminal Ganglia, nucleus and peripheral blood mononuclear cells in a rat orofacial pain model. Front Mol Neurosci. 11:219. https://doi.org/10.3389/fnmol.2018.00219

27. Dobin A, Davis CA, Schlesinger F, Drenkow J, Zaleski C, Jha S, Batut $P$, Chaisson M, Gingeras TR (2013) STAR: ultrafast universal RNA-seq aligner. Bioinformatics 29(1):15-21. https://doi.org/10.1093/bioinformatics/bts635

28. Liao Y, Smyth GK, Shi W (2019) The R package Rsubread is easier, faster, cheaper and better for alignment and quantification of RNA sequencing reads. Nucleic Acids Res 47(8):e47-e47. https://doi.org/10.1093/nar/gkz114

29. Robinson MD, McCarthy DJ, Smyth GK (2010) edgeR: a Bioconductor package for differential expression analysis of digital gene expression data. Bioinformatics 26:139-140

30. Law CW, Chen Y, Shi W, Smyth GK (2014) Voom: precision weights unlock linear model analysis tools for RNA-seq read counts. Genome Biol 15:R29

31. Ritchie ME, Phipson B, Wu D, Hu Y, Law CW, Shi W et al (2015) Limma powers differential expression analyses for RNA-sequencing and microarray studies. Nucleic Acids Res 43:e47

32. Luo W, Brouwer C (2013) Pathview: an R/Bioconductor package for pathway-based data integration and visualization. Bioinformatics 29:18301831

33. Uzar E, Evliyaoglu O, Yucel Y, Ugur Cevik M, Acar A, Guzel I, Islamoglu Y, Colpan L, Tasdemir N (2011) Serum cytokine and pro-brain natriuretic peptide (BNP) levels in patients with migraine. Eur Rev Med Pharmacol Sci 15(10):1111-1116

34. Covelli V, Massari F, Fallacara C, Munno I, Pellegrino NM, Jirillo E, Savastano S, Ghiggi MR, Tommaselli AP, Lombardi G (1991) Increased spontaneous release of tumor necrosis factor-alpha/cachectin in headache patients. A possible correlation with plasma endotoxin and hypothalamic-pituitaryadrenal axis. Int J Neurosci 61(1-2):53-60. https://doi.org/10.3109/002074591 08986270

35. Perini F, D’Andrea G, Galloni E, Pignatelli F, Billo G, Alba S et al (2005) Plasma cytokine levels in migraineurs and controls. Headache J Head Face Pain 45(7):926-931. https://doi.org/10.1111/j.1526-4610.2005.05135.x
36. Sarchielli P, Alberti A, Baldi A, Coppola F, Rossi C, Pierguidi L, Floridi A, Calabresi P (2006) Proinflammatory cytokines, adhesion molecules, and lymphocyte integrin expression in the internal jugular blood of migraine patients without aura assessed ictally. Headache. 46(2):200-207. https://doi. org/10.1111/j.1526-4610.2006.00337.x

37. McDonald JH (2014) Handbook of biological statistics, 3rd edn. Sparky House Publishing, Baltimore, Maryland, USA

38. Levy D, Burstein R, Kainz V, Jakubowski M, Strassman AM (2007) Mast cell degranulation activates a pain pathway underlying migraine headache. Pain 130(1-2):166-176. https://doi.org/10.1016/j.pain.2007.03.012

39. Conti P, D'Ovidio C, Conti C, Gallenga CE, Lauritano D, Caraffa A, Kritas SK, Ronconi G (2019) Progression in migraine: role of mast cells and proinflammatory and anti-inflammatory cytokines. Eur J Pharmacol 844:87-94 https://doi.org/10.1016/j.ejphar.2018.12.004

40. Kursun O, Yemisci M, van den Maagdenberg AMJM, Karatas H (2021) Migraine and neuroinflammation: the inflammasome perspective. J Headache Pain 22(1):55. https://doi.org/10.1186/s10194-021-01271-1

41. Duarte H, Teixeira AL, Rocha NP, Domingues RB (2015) Increased interictal serum levels of CXCL8/IL-8 and CCL3/MIP-1a in migraine. Neurol Sci 36(2): 203-208. https://doi.org/10.1007/s10072-014-1931-1

42. Domingues RB, Duarte $H$, Senne C, Bruniera G, Brunale F, Rocha NP, Teixeira AL (2016) Serum levels of adiponectin, CCL3/MIP-1a, and CCL5/RANTES discriminate migraine from tension-type headache patients. Arq Neuropsiquiatr 74(8):626-631. https://doi.org/10.1590/0004-282X20160096

43. Vanmolkot FH, de Hoon JN (2007) Increased C-reactive protein in young adult patients with migraine. Cephalalgia. 27(7):843-846. https://doi.org/1 $0.1111 / j .1468-2982.2007 .01324 . x$

44. Güzel I, Taşdemir N, Celik Y (2013) Evaluation of serum transforming growth factor $\beta 1$ and C-reactive protein levels in migraine patients. Neurol Neurochir Pol 47(4):357-362. https://doi.org/10.5114/ninp.2013.36760

45. Woolf CJ, Allchorne A, Safieh-Garabedian B, Poole S (1997) Cytokines, nerve growth factor and inflammatory hyperalgesia: the contribution of tumour necrosis factor a. Br J Pharmacol 121(3):417-424. https://doi.org/10.1038/sj. bjp.0701148

46. Watkins LR, Maier SF (2002) Beyond neurons: evidence that immune and glial cells contribute to pathological pain states. Physiol Rev 82:981-1011

47. Sommer C, Kress M (2004) Recent findings on how proinflammatory cytokines cause pain: peripheral mechanisms in inflammatory and neuropathic hyperalgesia. Neurosci Lett 361(1-3):184-187. https://doi.org/1 0.1016/j.neulet.2003.12.007

48. Kawasaki Y, Zhang L, Cheng J-K, Ji R-R (2008) Cytokine mechanisms of central sensitization: distinct and overlapping role of interleukin-1 $\beta$, Interleukin-6, and tumor necrosis factor-a in regulating synaptic and neuronal activity in the superficial spinal cord. J Neurosci 28(20):5189-5194. https://doi.org/10.1523/JNEUROSCI.3338-07.2008

49. Zhang X-C, Kainz V, Burstein R, Levy D (2011) Tumor necrosis factor-a induces sensitization of meningeal nociceptors mediated via local COX and p38 MAP kinase actions. Pain 152:140-149. https://doi.org/10.1016/j.pain.201 0.10 .002

50. Zhang X, Burstein R, Levy D (2012) Local action of the proinflammatory cytokines IL-1 and IL-6 on intracranial meningeal nociceptors. Cephalalgia. 32(1):66-72. https://doi.org/10.1177/0333102411430848

51. Silva RL, Lopes AH, Guimarães RM, Cunha TM (2017) CXCL1/CXCR2 signaling in pathological pain: role in peripheral and central sensitization. Neurobiol Dis 105:109-116. https://doi.org/10.1016/j.nbd.2017.06.001

52. Piotrowska A, Rojewska E, Pawlik K, Kreiner G, Ciechanowska A, Makuch W et al (2019) Pharmacological blockade of spinal CXCL3/CXCR2 signaling by NVP CXCR2 20, a selective CXCR2 antagonist, reduces neuropathic pain following peripheral nerve injury. Front Immunol 10:2198. https://doi.org/1 0.3389/fimmu.2019.02198

53. Manjavachi MN, Passos GF, Trevisan G, Araújo SB, Pontes JP, Fernandes ES, Costa R, Calixto JB (2019) Spinal blockage of CXCL1 and its receptor CXCR2 inhibits paclitaxel-induced peripheral neuropathy in mice. Neuropharmacology. 151:136-143. https://doi.org/10.1016/j.neuropharm.201 9.04.014

54. Moraes TR, Elisei LS, Malta IH, Galdino G (2020) Participation of CXCL1 in the glial cells during neuropathic pain. Eur J Pharmacol 875:173039. https://doi. org/10.1016/j.ejphar.2020.173039

55. Liang D-Y, Shi X, Liu P, Sun Y, Sahbaie P, Li W-W et al (2017) The chemokine receptor $C X C R 2$ supports nociceptive sensitization after traumatic brain injury. Mol Pain 13:1744806917730212 
56. Sahbaie P, Irvine K-A, Liang D-Y, Shi X, Clark JD (2019) Mild traumatic brain injury causes nociceptive sensitization through spinal chemokine upregulation. Sci Rep 9(1):19500. https://doi.org/10.1038/s41598-019-55739-x

57. Nees TA, Rosshirt N, Zhang JA, Reiner T, Sorbi R, Tripel E, Walker T, Schiltenwolf M, Hagmann S, Moradi B (2019) Synovial cytokines significantly correlate with osteoarthritis-related knee pain and disability: inflammatory mediators of potential clinical relevance. J Clin Med 8(9):1343. https://doi. org/10.3390/jcm8091343

58. Riese DJ, Cullum RL (2014) Epiregulin: Roles in normal physiology and cancer. Semin Cell Dev Biol 28:49-56. https://doi.org/10.1016/.semcdb.2014.03.005

59. Singh B, Carpenter G, Coffey RJ (2016) EGF receptor ligands: recent advances. F1000Res 5:2270. https://doi.org/10.12688/f1000research.9025.1

60. Martin LJ, Smith SB, Khoutorsky A, Magnussen CA, Samoshkin A, Sorge RE, Cho C, Yosefpour N, Sivaselvachandran S, Tohyama S, Cole T, Khuong TM, Mir E, Gibson DG, Wieskopf JS, Sotocinal SG, Austin JS, Meloto CB, Gitt JH, Gkogkas C, Sonenberg N, Greenspan JD, Fillingim RB, Ohrbach R, Slade GD Knott C, Dubner R, Nackley AG, Ribeiro-da-Silva A, Neely GG, Maixner W, Zaykin DV, Mogil JS, Diatchenko L (2017) Epiregulin and EGFR interactions are involved in pain processing. J Clin Investig 127(9):3353-3366. https://doi. org/10.1172/JCl87406

61. Yamane S, Ishida S, Hanamoto Y, Kumagai K, Masuda R, Tanaka K, Shiobara N, Yamane N, Mori T, Juji T, Fukui N, Itoh T, Ochi T, Suzuki R (2008) Proinflammatory role of amphiregulin, an epidermal growth factor family member whose expression is augmented in rheumatoid arthritis patients. J Inflamm 5(1):5. https://doi.org/10.1186/1476-9255-5-5

62. Gross EC, Lisicki M, Fischer D, Sándor PS, Schoenen J (2019) The metabolic face of migraine - from pathophysiology to treatment. Nat Rev Neurol 15(11):627-643. https://doi.org/10.1038/s41582-019-0255-4

63. Cevoli S, Favoni V, Cortelli P (2019) Energy metabolism impairment in migraine. Curr Med Chem 26(34):6253-6260. https://doi.org/10.2174/092 9867325666180622154411

64. Neri M, Frustaci A, Milic M, Valdiglesias V, Fini M, Bonassi S, Barbanti P (2015) A meta-analysis of biomarkers related to oxidative stress and nitric oxide pathway in migraine. Cephalalgia. 35(10):931-937. https://doi.org/10.1177/ 0333102414564888

65. Welch KM, Levine SR, D'Andrea G, Schultz LR, Helpern JA (1989) Preliminary observations on brain energy metabolism in migraine studied by in vivo phosphorus 31 NMR spectroscopy. Neurology. 39(4):538-541. https://doi. org/10.1212/WNL.39.4.538

66. Barbiroli B, Montagna P, Cortelli P, Funicello R, lotti S, Monari L, Pierangeli G, Zaniol P, Lugaresi E (1992) Abnormal brain and muscle energy metabolism shown by 31P magnetic resonance spectroscopy in patients affected by migraine with aura. Neurology. 42(6):1209-1214. https://doi.org/10.1212/ WNL.42.6.1209

67. Lodi R, Kemp GJ, Montagna P, Pierangeli G, Cortelli P, lotti S, Radda GK, Barbiroli B (1997) Quantitative analysis of skeletal muscle bioenergetics and proton efflux in migraine and cluster headache. J Neurol Sci 146(1):73-80. https://doi.org/10.1016/S0022-510X(96)00287-0

68. Kim JH, Kim S, Suh S-1, Koh S-B, Park K-W, Oh K (2010) Interictal metabolic changes in episodic migraine: a voxel-based FDG-PET study. Cephalalgia. 30(1):53-61. https://doi.org/10.1111/j.1468-2982.2009.01890.x

69. Borkum JM (2016) Migraine triggers and oxidative stress: A narrative review and synthesis: headache. Headache: The Journal of Head and Face Pain. 56(1):12-35. https://doi.org/10.1111/head.12725

70. Borkum JM (2018) The migraine attack as a homeostatic, neuroprotective response to brain oxidative stress: preliminary evidence for a theory Headache. 58(1):118-135. https://doi.org/10.1111/head.13214

71. Littlewood J, Glover V, Sandler M, Peatfield R, Petty R, Clifford RF (1984) Low platelet monoamine oxidase activity in headache: no correlation with phenolsulphotransferase, succinate dehydrogenase, platelet preparation method or smoking. J Neurol Neurosurg Psychiatry 47(4):338-343. https:// doi.org/10.1136/jnnp.47.4.338

72. Sangiorgi S, Mochi M, Riva R, Cortelli P, Monari L, Pierangeli G, Montagna P (1994) Abnormal platelet mitochondrial function in patients affected by migraine with and without aura. Cephalalgia. 14(1):21-23. https://doi.org/1 0.1046/j.1468-2982.1994.1401021.x

73. Okada H, Araga S, Takeshima T, Nakashima K (1998) Plasma lactic acid and pyruvic acid levels in migraine and tension-type headache. Headache. 38(1): 39-42. https://doi.org/10.1046/j.1526-4610.1998.3801039.x

74. Montagna P, Sacquegna T, Martinelli P, Cortelli P, Bresolin N, Moggio M, Baldrati A, Riva R, Lugaresi E (1988) Mitochondrial abnormalities in migraine.
Preliminary findings. Headache 28(7):477-480. https://doi.org/10.1111/j.152 6-4610.1988.hed2807477x

75. Magistretti PJ, Pellerin L (1999) Cellular mechanisms of brain energy metabolism and their relevance to functional brain imaging. Philos Trans $\mathrm{R}$ Soc Lond Ser B Biol Sci 354(1387):1155-1163. https://doi.org/10.1098/rstb.1 999.0471

76. Serena C, Ceperuelo-Mallafré V, Keiran N, Queipo-Ortuño MI, Bernal R, Gomez-Huelgas R et al (2018) Elevated circulating levels of succinate in human obesity are linked to specific gut microbiota. ISME J 12:1642-1657

77. D’Alessandro A, Moore HB, Moore EE, Reisz JA, Wither MJ, Ghasasbyan A, et al. (2017) Plasma succinate is a predictor of mortality in critically injured patients. J Trauma Acute Care Surg 83:491-495

78. Beloborodova N, Pautova A, Sergeev A, Fedotcheva N (2019) Serum Levels of Mitochondrial and Microbial Metabolites Reflect Mitochondrial Dysfunction in Different Stages of Sepsis. Metabolites 9:196. https://doi. org/10.3390/metabo9100196

79. Chouchani ET, Pell VR, Gaude E, Aksentijević D, Sundier SY, Robb EL et al (2014) Ischaemic accumulation of succinate controls reperfusion injury through mitochondrial ROS. Nature 515:431-435

80. Tannahill GM, Curtis AM, Adamik J, Palsson-McDermott EM, McGettrick AF, Goel $G$ et al (2013) Succinate is an inflammatory signal that induces IL-1ß through HIF-1a. Nature 496:238-242

81. Chinopoulos C (2019) Succinate in ischemia: where does it come from? Int Biochem Cell Biol 115:105580. https://doi.org/10.1016/j.biocel.2019.105580

82. Mills $E$, O'Neill LAJ (2014) Succinate: a metabolic signal in inflammation. Trends Cell Biol 24(5):313-320. https://doi.org/10.1016/j.tcb.2013.11.008

83. Narayanan SP, Shosha E, Palani CD (2019) Spermine oxidase: A promising therapeutic target for neurodegeneration in diabetic retinopathy. Pharmaco Res 147:104299

84. Mandal S, Mandal A, Park MH (2015) Depletion of the polyamines spermidine and Spermine by overexpression of spermidine/spermine N1Acetyltransferase1 (SAT1) leads to mitochondria-mediated apoptosis in mammalian cells. Biochem J 468(3):435-447. https://doi.org/10.1042/BJ201 50168

85. Salvi M, Toninello A (2004) Effects of polyamines on mitochondrial Ca2+ transport. Biochim Biophys Acta Biomembr 1661(2):113-124. https://doi. org/10.1016/j.bbamem.2003.12.005

86. Ha HC, Sirisoma NS, Kuppusamy P, Zweier JL, Woster PM, Casero RA (1998) The natural polyamine spermine functions directly as a free radical scavenger. Proc Natl Acad Sci U S A 95(19):11140-11145. https://doi.org/1 0.1073/pnas.95.19.11140

87. Pegg AE (2014) The function of spermine. IUBMB Life 66(1):8-18. https://doi. org/10.1002/iub.1237

88. Hu J, Lu X, Zhang X, Shao X, Wang Y, Chen J, et al. Exogenous spermine attenuates myocardial fibrosis in diabetic cardiomyopathy by inhibiting endoplasmic reticulum stress and the canonical Wnt signaling pathway. Cell Biol Int 44:1660-1670. https://doi.org/10.1002/cbin.11360

89. Soda K (2020) Spermine and gene methylation: a mechanism of lifespan extension induced by polyamine-rich diet. Amino Acids 52(2):213-224. https://doi.org/10.1007/s00726-019-02733-2

90. Krauss M, Langnaese K, Richter K, Brunk I, Wieske M, Ahnert-Hilger G, Veh RW Laube $G$ (2006) Spermidine synthase is prominently expressed in the striatal patch compartment and in putative interneurones of the matrix compartment. J Neurochem 97(1):174-189. https://doi.org/10.1111/j.1471-4159.2006.03721.x

91. Skatchkov S, Woodbury M, Eaton M (2014) The role of glia in stress: polyamines and brain disorders. Psychiatr Clin North Am 37(4):653-678. https://doi.org/10.1016/j.psc.2014.08.008

92. Skatchkov SN, Bukauskas FF, Benedikt J, Inyushin M, Kucheryavykh YV (2015) Intracellular spermine prevents acid-induced uncoupling of $\mathrm{C} \times 43$ gap junction channels. NeuroReport. 26(9):528-532. https://doi.org/10.1097/WNR. 0000000000000385

93. Benedikt J, Inyushin M, Kucheryavykh YV, Rivera Y, Kucheryavykh LY, Nichols CG, Eaton MJ, Skatchkov SN (2012) Intracellular polyamines enhance astrocytic coupling. Neuroreport. 23(17):1021-1025. https://doi.org/10.1097/ WNR.0b013e32835aa04b

94. Skatchkov SN, Eaton MJ, Krusek J, Veh RW, Biedermann B, Bringmann A et a (2000) Spatial distribution of spermine/spermidine content and $K(+)$-current rectification in frog retinal glial (Müller) cells. Glia. 31(1):84-90. https://doi. org/10.1002/(SICI)1098-1136(200007)31:1<84:.:AID-GLIA80>3.0.CO;2-7

95. Lourenço dos Santos S, Petropoulos I, Friguet B (2018) The oxidized protein repair enzymes methionine sulfoxide reductases and their roles in 
protecting against oxidative stress, in ageing and in regulating protein function. Antioxidants 7:191. https://doi.org/10.3390/antiox7120191

96. Deng Y, Marsh BM, Moskovitz J (2019) Increased levels of proteinmethionine sulfoxide in plasma correlate with a shift from a mild cognitive impairment to an Alzheimer's disease stage. Innov Clin Neurosci 16(7-08): 29-31

97. Vanhooren V, Navarrete Santos A, Voutetakis K, Petropoulos I, Libert C, Simm A, Gonos ES, Friguet B (2015) Protein modification and maintenance systems as biomarkers of ageing. Mech Ageing Dev 151:71-84. https://doi. org/10.1016/.jmad.2015.03.009

98. Oien DB, Moskovitz J (2019) Genetic regulation of longevity and ageassociated diseases through the methionine sulfoxide reductase system. Biochim Biophys Acta Mol Basis Dis 1865:1756-1762. https://doi.org/10.101 6/j.bbadis.2018.11.016

99. Onorato JM, Thorpe SR, Baynes JW (1998) Immunohistochemical and ELISA assays for biomarkers of oxidative stress in aging and disease. Ann N Y Acad Sci 854:277-290. https://doi.org/10.1111/j.1749-6632.1998.tb09909.x

\section{Publisher's Note}

Springer Nature remains neutral with regard to jurisdictional claims in published maps and institutional affiliations.

Ready to submit your research? Choose BMC and benefit from:

- fast, convenient online submission

- thorough peer review by experienced researchers in your field

- rapid publication on acceptance

- support for research data, including large and complex data types

- gold Open Access which fosters wider collaboration and increased citations

- maximum visibility for your research: over $100 \mathrm{M}$ website views per year

At $\mathrm{BMC}$, research is always in progress.

Learn more biomedcentral.com/submissions 